\title{
PKM Pemanfaatan Media Sosial sebagai Sarana Promosi bagi UKM Kripik Singkong Gazal Makmur di Desa Kotaanyar pada Masa New Normal
}

Cahyuni Novia $^{1 *}$, Firda Meiliya Hendriana ${ }^{2}$, Fiyan Aprilia Vionata ${ }^{3}$, Ira Alfa Ida4 , Irna Charisma Damaiyanti ${ }^{5}$, Ismiatul Maula ${ }^{6}$, Syifa Fauziah7, Ulfatur Rahma ${ }^{8}$

\author{
Universitas Nurul Jadid Probolinggo $1,2,3,4,5,6,7,8$ \\ \{vhie771108@gmail.com ${ }^{1}$, firdameiliya@gmail.com², fiyanav@gmail.com³ ${ }^{3}$,iraalfa88139@gmail.com , \\ irnacharismadamaiyanti@gmail.com ${ }^{5}$, ismiatulmaulana@gmail.com ${ }^{6}$, syifafni15@gmail.com \\ ulfaturrahmah630@gmail.com $\left.{ }^{8}\right\}$
}

\begin{tabular}{|c|c|}
\hline Submission: & Received: 31/12/2021 \\
\hline $\begin{array}{l}\text { Keywords: } \\
\text { Social media, } \\
\text { Promotion, } \\
\text { SME }\end{array}$ & $\begin{array}{l}\text { Abstract. Currently, Small and Medium Enterprises (SMEs) both in } \\
\text { the service and production sectors are experiencing severe } \\
\text { challenges in the conditions of the Covid-19 pandemic. SMEs actors } \\
\text { present a new era order and a new normal or better known as the } \\
\text { New Normal. The New Normal era provides both challenges and } \\
\text { opportunities for SMEs. Social media is currently the most effective } \\
\text { media used in promotional activities. Most SMEs use social media to } \\
\text { make personal contact with consumers, promote/advertise, collect } \\
\text { data on consumer needs and provide feedback to consumers. This } \\
\text { community service activity aims to assist and provide training to } \\
\text { Gazal Makmur SMEs in selling through social media using Facebook, } \\
\text { YouTube, Instagram and TikTok applications. The results achieved in } \\
\text { this service are the prosperous Gazal SMEs can improve their ability } \\
\text { to utilize technology, especially to use social media application } \\
\text { products TikTok, YouTube, Instagram and Facebook. Viewers on } \\
\text { YouTube app accounts have a faster number of views than TikTok, } \\
\text { while Facebook followers have more followers than Instagram. }\end{array}$ \\
\hline
\end{tabular}

Katakunci: Media sosial, Promosi, UKM

\begin{abstract}
Abstrak. Pelaku Usaha Kecil dan Menengah (UKM) pada saat ini baik di sektor usaha jasa maupun produksi mengalami beragam tantangan berat dalam kondisi pandemi Covid-19. Pelaku UKM dihadapkan pada era tatanan baru dan kenormalan baru atau lebih dikenal dengan sebutan New Normal. Era New Normal memberikan tantangan sekaligus peluang bagi pelaku UKM. Media sosial saat ini media yang paling efektif digunakan dalam kegiatan promosi. Media sosial dimanfaatkan sebagian besar UKM untuk mengadakan kontak personal dengan konsumen, promosi/ advertising, melakukan pendataan kebutuhan konsumen dan menyampaikan respon ke konsumen. Kegiatan pengabdian kepada masysrakat ini bertujuan untuk mendampingi dan memberikan pelatihan kepada UKM Gazal Makmur dalam mempromosikan produknya melalui media sosial menggunakan aplikasi Facebook, You tube, Instagram dan TikTok. Hasil yang dicapai dalam kegiatan pengabdian ini adalah UKM Gazal makmur dapat meningkatkan
\end{abstract}




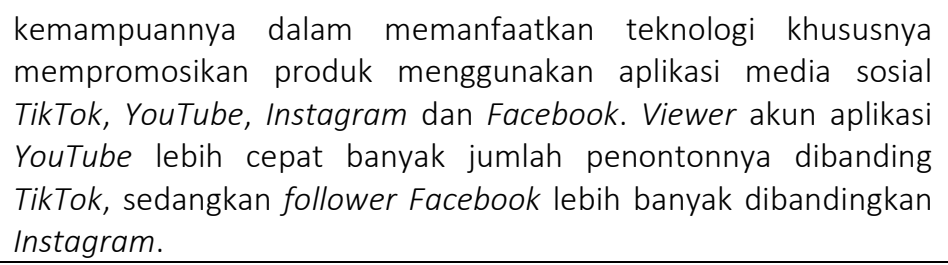

\section{Pendahuluan}

Era New Normal memberikan tantangan sekaligus peluang bagi pelaku UKM. Pemasaran secara online melalui media merupakan langkah tepat yang harus dilakukan oleh para pelaku usaha dimasa pandemi (Suswanto dan Setiawati, 2020; Gu et al., 2020). Penggunaan internet dalam pasar bisnis saat ini begitu luas, hal ini menjadi salah satu faktor yang menyebabkan munculnya model periklanan baru yaitu melalui platform media internet atau secara online yang kemudian biasa disebut dengan pemasaran digital (digital marketing). Digital marketing adalah suatu cara untuk mempromosikan produk atau brand tertentu melalui media internet dapat melalui iklan di internet, Facebook, YouTube, ataupun media sosial lainnya (Warmayana, 2018). Media sosial memberikan kesempatan bagi pengguna untuk memberi komentar dan berbagi informasi dalam waktu yang tidak terbatas secara gratis (Nasrullah, 2015). Data dari wearesocial menunjukkan bahwa per Januari 2018 pengguna internet di Indonesia mencapai 132,7 juta dengan tingkat penetrasi terhadap populasi sebesar 50\% dari populasi 262 juta jiwa. Dari survei ini juga ditemukan pengguna aktif social media yang mengakses menggunakan perangkat mobile yaitu sejumlah 120 juta jiwa. Tingginya tingkat penggunaan internet dipicu oleh perkembangan infrastruktur dan mudahnya mendapatkan smartphone atau perangkat genggam (Kemp, 2018). Media sosial adalah sebuah pengembangan bentuk kreasi informasi dan interaksi yang mempunyai potensi signifikan untuk pemasaran (Jansen et al., 2011).

Desa Kotaanyar merupakan desa yang terletak di wilayah Kecamatan Paiton Provinsi Jawa Timur. Mayoritas penduduk Desa Kotaanyar adalah bertani, penghasilan para petani tidak seberapa dan memerlukan waktu sekitar 3-4 bulan untuk panen. Hal tersebut menjadikan salah satu penggerak terlahirnya kegiatan yang diciptakan oleh masayarakat disana ialah berwirausaha. Home Industry menjadi pilihan masyarakat Kotaanyar, mereka mengelola hasil alam daerah sekitar yaitu ketela pohon/singkong (bahan mentah) menjadi kripik. Home industry menjadi penyelamat bagi kehidupan 
masyarakat baik itu penyelamat keuangan maupun lapangan pekerjaan sehingga pendapatan masyarakat sekitar menjadi meningkat. Lokasi KKN pengabdian ini ialah UKM kripik singkong gazal makmur. Gazal makmur merupakan sebuah UKM yang memproduksi cemilan kripik singkong. Saat ini UKM Gazal makmur belum pernah melakukan promosi produk menggunakan media sosial. Hanya melalui kegiatan promosi yang disediakan oleh pemerintah dan dinas terkait serta sales-sales yang dimiliki oleh UKM Gazal Makmur. Hal ini disebabkan kurangnya keterampilan dan pengetahuan yang dimiliki oleh pemilik UKM mengenai pemanfaatan media sosial sebagai sarana promosi produk.

Pandemi COVID-19 yang telah terjadi di Indonesia merupakan bencana yang tidak pernah diduga sebelumnya. Pada kondisi perekonomian yang sulit di tengah krisis ekonomi dunia, bangsa Indonesia juga harus menghadapi fenomena terjadinya pandemi COVID-19 yang semakin memberatkan pertumbuhan ekonomi. Berdasarkan latar belakang yang telah diuraikan, maka tim Kuliah Kerja Nyata (KKN) untuk program Pengabdian Kepada Masyarakat (PKM) akan melakukan kegiatan pengabdian pendampingan dan pelatihan dalam pemanfaatan media sosial sebagai sarana promosi bagi UKM Kripik Singkong Gazal Makmur di Desa Kotaanyar pada masa new normal. Kegiatan ini bertujuan untuk membuat suatu strategi pemasaran dengan memanfatkan media sosial seperti aplikasi Facebook, youtobe, tik-tok, instragram sebagai sarana promosi produk dalam memperluas wilayah pemasaran dan meningkatkan volume penjualan Kripik Singkong Gazal Makmur.

\section{Metode}

Metode Pengabdian Kepada Masyarakat (PKM) yang dilakukan pada kegiatan tim KKN ini adalah melakukan pendampingan dan pelatihan promosi melalui media sosial YouTube, Instagram, Facebook dan Tik-tok pada UKM keripik singkong Gazal Makmur. Gambar 1 menunjukkan tahapan-tahapan pelaksanaan kegiatan PKM. 


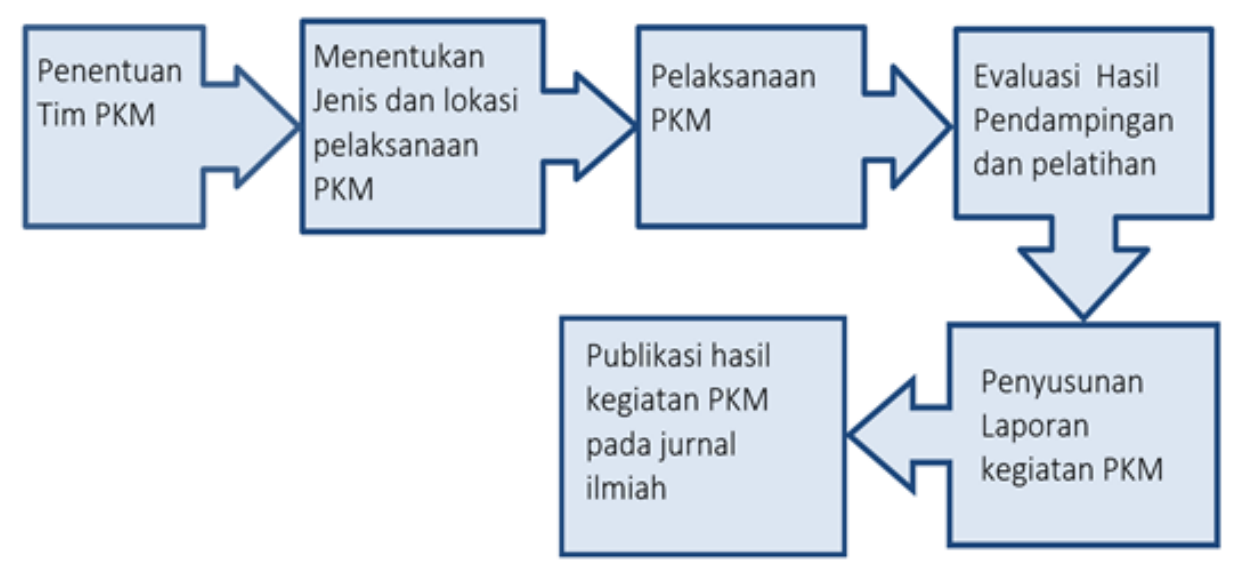

Gambar 1. Tahapan Pelaksanaan Pengabdian Kepada Masyarakat (PKM)

Penjelasan mengenai setiap tahapan kegiatan Pelaksanaan Pengabdian kepada Masyarakat (PKM) sebagai berikut:

1. Membentuk panitia kegiatan yang disebut tim KKN PKM yang terdiri dari 8 anggota yang terdiri dari satu orang dosen dari prodi Teknik Informatika berperan sebagai tutor, konseptor, dan fasilitator. Sedangkan 7 orang mahasiswi program KKN prodi Teknik Informatika.

2. Tim KKN PKM menentukan materi pendampingan dan pelatihan serta menentukan lokasi kegiatan PKM yang sesuai dengan tema dan materi PKM.

3. Pelaksanaan kegiatan PKM di UKM Gazal Makmur desa Kotaanyar dengan melakukan pendampingan dan pelatihan UKM dalam penggunaan akun aplikasi media sosial yang sudah dibuat oleh tim KKN PKM yaitu Facebook, YouTobe, Tik-Tok dan Instragram.

4. Melakukan evaluasi terhadap semua target kegiatan PKM. Menurut Nurhasanah et al., (2021) evaluasi merupakan suatu proses kegiatan untuk melakukan penilaian dan kajian ulang terhadap suatu pelaksanaan kegiatan sehingga akan diperoleh keunggulan dan kelemahan atas kegiatan tersebut yang dapat dijadikan sebagai referensi untuk dapat melaksanakan kegiatan yang berikutnya sehingga dapat meminimalisir kendala-kendala yang muncul, dan dapat lebih baik lagi

5. Penyusunan laporan kegiatan PKM sebagai bukti pertanggungjawaban program KKN. 
6. Publikasi kegiatan pengabdian kepada masyarakat dalam jurnal ilmiah yang bertujuan untuk menambah referensi ilmiah yang terkait dengan pelaksanaan pengabdian kepada masyarakat khususnya pemanfaatan aplikasi media sosial sebagai sarana promosi.

\section{Hasil}

Kegiatan Program KKN untuk Pengabdian Kepada Masyarakat ini memiliki target dan luaran sebagai wujud memanfatkan media sosial sebagai sarana promosi UKM keripik singkong gazal makmur. Adapun target dan luaran yang di hasilkan dari kegiatan dapat dilihat pada Tabel 1.

Tabel 1. Target dan luaran program pengabdian

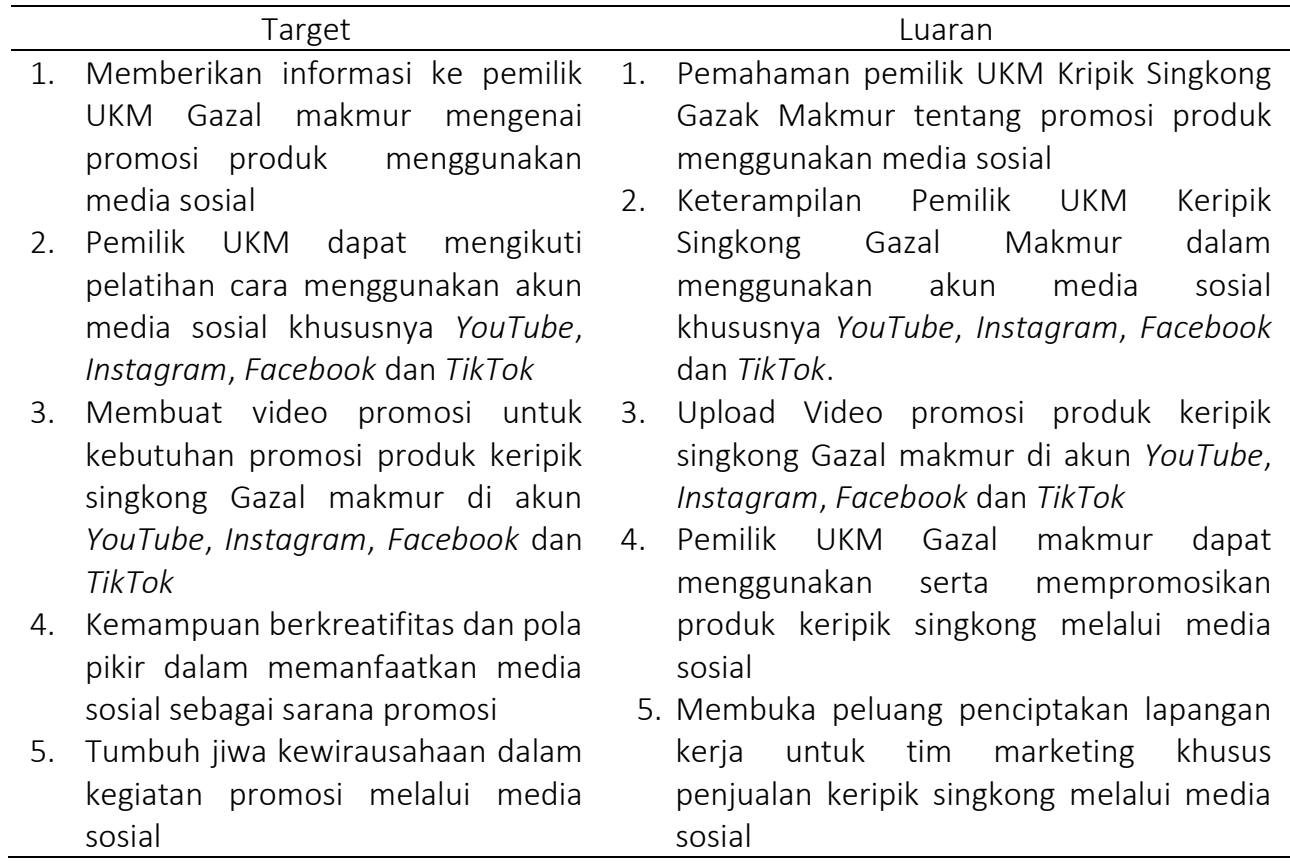

Dalam mencapai target dan luaran yang sudah ditetapkan dalam kegiatan PKM ini maka tim KKN PKM melakukan kegiatan sesuai dengan tahap-tahap sebagai berikut:

1. Membentuk panitia kegiatan yang disebut tim KKN PKM yang terdiri dari 8 anggota yang terdiri dari satu orang dosen prodi Teknik Informatika berperan sebagai tutor, konseptor, dan fasilitator. Serta 7 orang 
mahasiswi program KKN prodi Teknik Informatika. Kegiatan ini dilakukan dengan memanfaatkan aplikasi telegram dan zoom.

2. Tim KKN PKM menentukan materi pendampingan dan pelatihan kemudian menentukan lokasi kegiatan PKM yang sesuai dengan tema dan materi PKM. Setelah itu pembuatan materi untuk setiap akun media sosial yang akan digunakan sebagai media promosi. Masing-masing anggota tim KKN PKM mempunyai tanggung jawab terhadap materi dan akun aplikasi media sosial yang digunakan mulai dari pembuatan akun sampai melakukan monitoring respon dari para follower maupun viewer.
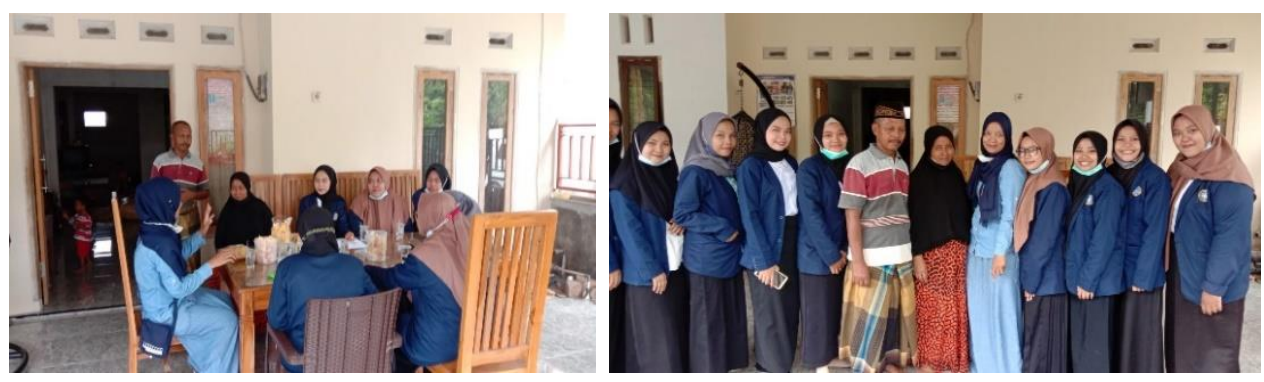

Gambar 2. Dokumentasi Kegiatan Pelaksanaan kegiatan PKM di UKM Gazal Makmur

3. Pelaksanaan kegiatan PKM di UKM Gazal Makmur desa Kotaanyar dengan melakukan pendampingan dan pelatihan pada pemilik UKM dalam penggunaan akun aplikasi media sosial yang sudah dibuat oleh tim PKM yaitu Facebook, YouTube, Tik-Tok dan Instragram. Berikut merupakan link akun aplikasi media sosial yang dibuat oleh tim KKN PKM sebagai media promosi produk keripik singkong UKM Gazal Makmur. 
a. Link Facebook

https://www.Facebook.com/profile.php?id=100069779251280

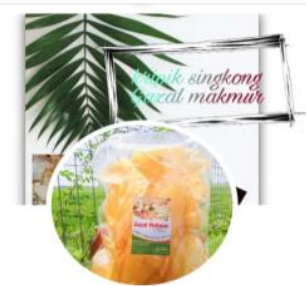

Gazal Makmur

o Message $\quad$ ?

Lives in Kota-Anyar, Jawa

Timur, Indonesia

- From Kota-Anyar, Jawa Timur,

... See Gazal's About Info

Friends

107 friends

Gambar 3. Beranda Facebook Keripik singkong Gazal Makmur

b. Link YouTube

Link YouTube : https://youtu.be/RLZ7Bb5KebQ

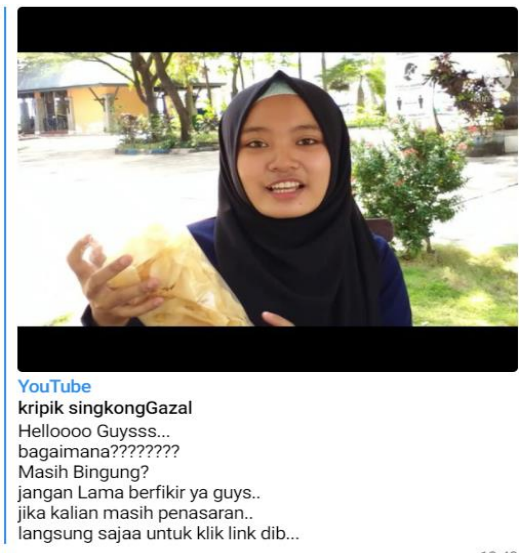

Gambar 4. Halaman utama Channel YouTube Keripik singkong Gazal Makmur 
c. Link TikTok

https://vt.TikTok.com/ZSJbpx4KD/

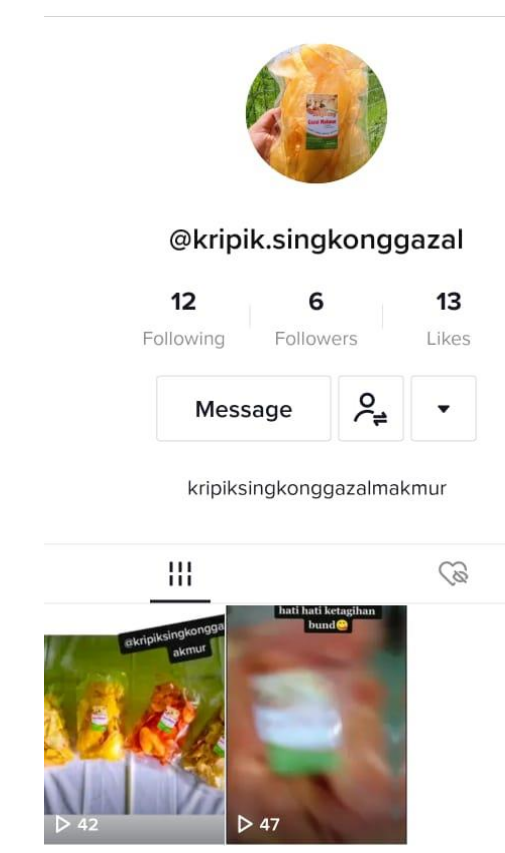

Gambar 5. Halaman Profil TikTok Keripik singkong Gazal Makmur

\section{d. Link Instagram}

https://Instagram.com/kripik.singkonggazal?utm_medium=copy_link
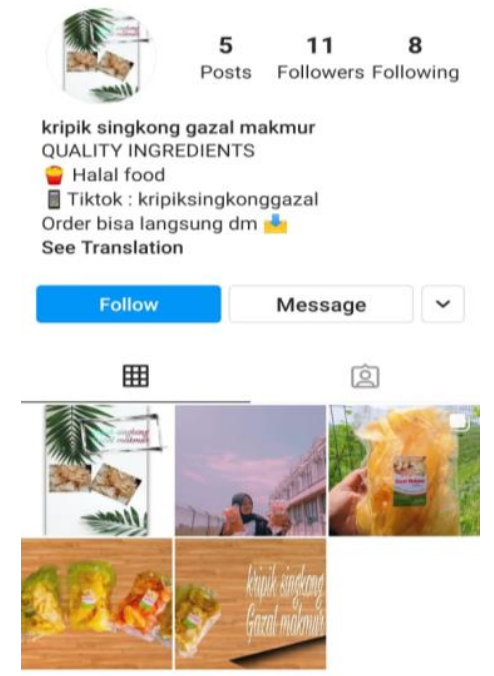

Gambar 5. Halaman Profil Instagram Keripik singkong Gazal makmur 
4. Melakukan evaluasi terhadap semua target kegiatan PKM.

Tim PKM mengevaluasi materi promosi yang sudah di upload pada setiap akun aplikasi dan melihat semua respons dari follower maupun viewer sebagai bahan untuk koreksi untuk pembuatan laporan kegiatan PKM dan sebagai dasar referensi untuk penyusunan artikel ilmiah yang akan dipublikasikan. Hasil yang diperoleh bahwa viewer YouTube lebih banyak dibandingkan viewer TikTok, dan follower Facebook lebih banyak dibandingkan Instagram.

\section{Pembahasan}

Usaha Kecil Menengah (UKM) saat ini berada di era baru dengan memanfaatkan media sosial sebagai jalan untuk promosi dan komunikasi pemasarannya (Amoah dan Jibril, 2020). Hal ini juga sesuai dengan hasil penelitian (Jibril et al., 2019) yaitu UKM di negara maju dapat berkembang melalui pemanfaatan media sosial sebagai alat untuk promosi dan komunikasi untuk keberlanjutan Pemasaran inovatif. Memanfaatkan media sosial yang diadopsi pada sebagian besar negara berkembang telah menurunkan kebiasaan UKM dari penggunaan strategi pemasaran dengan cara tradisional. Menurut Asiodu et al. (2015), media sosial didefinisikan sebagai penilaian informasi dari internet dan sumber lain melalui penggunaan smartphone atau komputer dari berbagai website dan aplikasi. Penelitian yang dilakukan oleh Fleming-Milici dan Harris (2020) menghasilkan bahwa $45 \%$ remaja terlibat dalam merespon merk makanan ringan. Promosi merk makanan melalui media sosial yang merupakan peningkatan strategi pemasaran dengan target remaja.

Berdasarkan temuan yang diperoleh pada saat melakukan pengabdian, diketahui bahwa UKM keripik Gazal Makmur belum pernah memanfaatkan aplikasi media sosial untuk mempromosikan produk-produknya. Hal ini disebabkan karena pemilik tidak memiliki pengetahuan mengenai bagaimana cara menggunakan aplikasi media sosial untuk promosi produk. Keadaan ini sesuai dengan penelitian yang dilakukan oleh Amoah dan Jibril (2020) yang dilakukan pada 512 responden staf manajerial industri fashion di Ghana bagian tengah yang menunjukkan bahwa kurangnya keterampilan manajerial/keahlian pemasaran, merupakan faktor penghambat signifikan yang mempengaruhi penerapan media sosial sebagai alat promosi dan 
komunikasi di kalangan UKM dalam mengembangkan ekonomi. Penelitian ini juga diperkuat oleh Dekker et al. (2020) menyatakan bahwa kurangnya keterampilan manajerial/keahlian memiliki hubungan negatif dengan adopsi media sosial oleh UKM di industri fashion di bagian tengah negara ini untuk promosi atau pemasarannya.

Beberapa cara dapat dilakukan oleh UKM untuk mampu bertahan dalam kondisi pandemi ini. UKM memanfaatkan media sosial untuk dapat menjangkau konsumennya secara langsung dan dapat menekan biaya promosi (Prasetyawati et al., 2021). Jumlah penduduk Indonesia yang aktif menggunakan media sosial pada bulan Januari 2020 sebesar 59\%. Rata-rata masyarakat menghabiskan waktu dalam sehari untuk menggunakan media sosial adalah selama 3 jam 26 menit (Kemp, 2020). Hasil dari kegiatan pelaksanaan pengabdian untuk promosi di media sosial didapatkan bahwa akun YouTube lebih banyak di respon dan dilihat bila dibandingkan TikTok. Gambar 6 merupakan perbandingan viewer TikTok dan YouTube, terlihat bahwa 1 video yang diunggah diYouTube sudah ditonton senyak 65 kali dan 1 video yang diunggah diTikTok ditonton masih dibawah 50 kali.

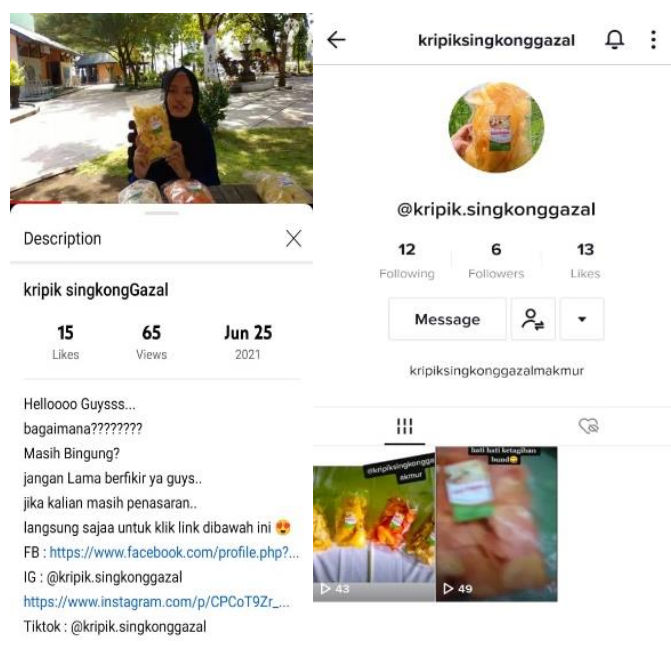

Gambar 6. Perbandingan viewer TikTok dan YouTube

Hal ini sesuai dengan hasil penelitian Andhika (2020) menyatakan bahwa penggunaan YouTube lebih efektif dilihat dari kemudahan dan efisiensi dalam kegiatan promosi. Menurut Patiwi et al. (2020), data persentase terbesar di Indonesia pada pengguna yang mengakses YouTube mencapai 88\% dibandingkan media sosial lain. YouTube merupakan salah satu layanan dari 
situs Google yang memfasilitasi penggunanya untuk mengupload video yang bisa diakses dan dinikmati oleh pengguna Internet dari seluruh dunia secara gratis (Faiqah et al., 2016). TikTok adalah aplikasi media sosial yang berfokus pada berbagi video pendek. Pengguna dapat mengambil keuntungan dari bermacam-macam template, filter, dan efek visual, serta perpustakaan musik bawaan, untuk membuat video pendek (Su et al.,2020). Menurut Ayesh (2016) bahwa salah satu strategi pemasaran yang bertujuan untuk menarik calon konsumen dengan cara membuat konten-konten yang menarik dan beragam informasi yang dibutuhkan oleh konsumen berupa artikel, video, foto, hasil riset, dan sebagainya.

Hasil pelaksanaan PKM juga menunjukkan bahwa akun aplikasi Facebook lebih cepat menambah follower daripada Instagram. Hal ini sesuai dengan data pengguna media sosial di Indonesia, Facebook berada di peringkat ketiga sebagai aplikasi media sosial yang banyak digunakan dengan jumlah pengguna sebanyak $82 \%$ dari jumlah pengguna internet di Indonesia sedangkan Instagram berada di urutan keempat dengan jumlah pengguna 79\% dari jumlah pengguna internet di Indonesia (Ratri,2020). Instagram adalah aplikasi yang memberikan fasilitas berbagi foto maupun video, mengambil foto, menerapkan filter digital, dan membagikannya ke berbagai layanan jejaring sosial, termasuk milik Instagram sendiri (Yasundari, 2016). Facebook adalah situs jejaring sosial yang memungkinkan pengguna dapat saling berinteraksi dengan pengguna lainnya di seluruh dunia dengan jaringan internet (Tasliman dan Suryawibawa, 2019). Facebook juga memiliki fasilitas untuk mengembangkan bisnis lewat fitur yang sudah disediakan. Hal ini sangat mendukung para pengguna untuk melakukan kegiatan bisnis maupun promosi di platform ini.

\section{Kesimpulan}

Kegiatan PKM dengan melakukan pendampingan dan pelatihan mengenai Pemanfaatan Media Sosial Sebagai Sarana Promosi Bagi UKM Kripik Singkong Gazal Makmur Di Desa Kotaanyar pada Masa New Normal telah sesuai dengan target dan luaran yang telah ditetapkan. Hal ini sudah dapat terlihat pada peningkatan pengetahuan dan keterampilan pemilik UKM dalam pemanfaatan teknologi khususnya media sosial sebagai media promosi produk keripik singkong menggunakan aplikasi media sosial TikTok, YouTube, 
Instagram dan Facebook. Viewer akun aplikasi YouTube lebih cepat banyak jumlah penontonnya dibanding TikTok, sedangkan follower Facebook lebih banyak dibandingkan Instagram.

\section{Pengakuan}

Tim KKN PKM mengucapkan terimakasih banyak atas kerjasamanya kepada UKM keripik singkong Gazal Makmur selaku mitra pada pelaksanaan KKN PKM dan LP3M Universitas Nurul Jadid yang telah memberi amanah kepada tim KKN PKM untuk melaksanakan kegiatan pendampingan dan pelatihan.

\section{Referensi}

Amoah, J., \& Jibril, A. B. (2020). Inhibitors Of Social Media as an Innovative Tool for Advertising and Marketing Communication: Evidence from Smes in A Developing Country. Innovative Marketing, 16(4), 164-179. http://dx.doi.org/10.21511/im.16(4).2020.15

Andhika, A. (2020). Penggunaan Video Promosi Wisata Melalui YouTube Untuk Meningkatkan Daya Tarik Wisatawan Ke Provinsi Kalimantan Selatan. Jurnal Mutakallimin: Jurnal IImu Komunikasi, 2(2), 26-30.

Asiodu, I. V., Waters, C. M., Dailey, D. E., Lee, K. A., \& Lyndon, A. (2015). Breastfeeding and Use of Social Media Among FirstTime African American Mothers. JOGNN - Journal of Obstetric, Gynecologic, and Neonatal Nursing, 44(2), 268-278. https://doi. org/10.1111/15526909.12552

Ayesh, G. (2016). Strategi Internet Marketing Band Indie Pekan Baru Dalam Mempromosikan karya Musik Melalui Reverbnation. Com.JOM FISIP, 3(1), 1-18.

Dekker, R., van den Brink, P., \& Meijer, A. (2020). Social Media Adoption In The Police: Barriers And Strategies. Government Information Quarterly, 37(2), 101441. https://doi.org/10.1016/j. giq.2019.101441 
Faiqah, F., Nadjib, M., \& Amir, A. S. (2016). YouTube Sebagai Sarana Komunikasi Bagi Komunitas Makassarvidgram. Jurnal Komunikasi KAREBA, 5(2).

Gu, J., Han, B., \& Wang, J. (2020). Covid19: Gastrointestinal Manifestations and Potential Fecal-Oral Transmission. Journal Gastroenterology, 158(6), 1518- 1519.

Jansen, B. J., Sobel, K., \& Cook, G. (2011). Classifying Ecommerce Information Sharing Behaviour By Youths On Social Networking Sites. Journal of Information Science, 37(2), 120-136.

Jibril, A. B., Kwarteng, M. A., Chovancova, M., \& Pilik, M. (2019). The Impact Of Social Media On Consumer-Brand Loyalty: A Mediating Role Of Online Based Brand Community. Cogent Business \& Management, 6(1), 1673640 .

Kemp, S. (2018). Digital in 2018 : World's Internet Users Pass The 4 Billion Mark. https://wearesocial.com/blog/2018/01/global-digital-report2018

Kemp, S. (2020). Digital in 2020: New Decade, New Milestones. https://wearesocial.com/digital-2020.

Nasrullah, Rulli.(2017) Media Sosial Perspektif Komunikasi, Budaya dan Sosioteknologi. Jakarta: Simbiosa Rekatama Media

Nurhasanah, E., Tasia, F. E., Kurniawan, W., Afriliani, F., \& Soffiatun, S. (2021).

Pelatihan Pembuatan Chanel YouTube Sebagai Media Promosi Pendidikan Digital Pada Yayasan Kusuma Cahaya Gemilang Cipondoh Tangerang. JAMAIKA: Jurnal Abdi Masyarakat, 2(2).

Prasetyawati, Y. R., Setyaningtyas, E., Ayu, J. P., Sartika, K. D., \& Adithia, S. (2021). Pelatihan Culinary Entrepreneur Dalam Mengembangkan Kinerja UMKM di Masa Pandemi. Journal of Servite, 3(1), 31-43.

Ratri, A.K. (2020). Analisis Keamanan Browser Menggunakan Metode National Institute Of Justice (Studi Kasus: Facebook Dan Instagram). (Doctoral dissertation, Institut Teknologi Telkom Purwokerto). 
Su, Y., Baker, B.J., Doyle, J.P., \& Yan, M. (2020). Fan Engagement In 15 Seconds: Athletes' Relationship Marketing During A Pandemic Via TikTok. International Journal of Sport Communication, 13(3), 436-446.

Suswanto, P., \& Setiawati, S. D. (2020). Strategi Komunikasi Pemasaran Shopee Dalam Membangun Positioning di Tengah Pandemi Covid-19 di Indonesia. Linimasa: Jurnal IImu Komunikasi, 3(2), 16- 29

Tasliman, M., \& Suryawibawa, D. T. (2019). Analisis Pemanfaatan Facebook Sebagai Media Promosi Produk Perumahan Syariah di PT. Jannata Land. Prosiding, 940-945.

Warmayana, I. G. A. K. (2018). Pemanfaatan Digital Marketing Dalam Promosi Pariwisata Pada Era Industri 4.0. Pariwisata Budaya: Jurnal IImiah Agama Dan Budaya, 3(2), 81-92.

Yasundari. (2016). Hubungan Penggunaan Instagram Dengan Motivasi Wirausaha Pebisnis Daring (Online) Dalam Meningkatkan Produktivitas. Jurnal Kajian Komunikasi, 4, 208-218.

Fleming-Milici, F., \& Harris, J. L. (2020). Adolescents' engagement with unhealthy food and beverage brands on social media. Appetite, 146, 104501. 